New Zealand Journal of Industrial Relations, 19(3): 233-234

\title{
SYMPOSIUM:
}

\section{LABOUR MARKET DEREGULATION: PERSPECTIVES FROM NEW ZEALAND AND ABROAD}

\section{Introduction}

\section{Alan Geare and Ian McAndrew}

It is now nearly four years since the enactment of New Zealand's Employment Contracts Act 1991. Since then this journal has had two symposia on industrial law. One, in August 1991, considered the implications of the Act and another, two years later, considered the changes proposed by the Labour Opposition. It was decided to have this third symposium for two main reasons. The first was to enable leading writers to reflect back on the changes wrought by the Act, rather than simply predicting consequences. The second reason was to help the Journal's readership put the Act into international perspective by considering significant changes in industrial law overseas. To meet these two objectives the Journal invited two papers from leading New Zealand authors and three from leading Australian and British authors.

Kevin Hince and Raymond Harbridge provide an assessment of the Employment Contracts Act - acknowledging it created a boom for academic writing. (The citations at the end of their paper bear this out). They demonstrate the impact the Act has had both on collective bargaining and on unionism in New Zealand, and speculate on its impact on employment and equity. They conclude that the advantages attributable to the Act could have been achieved with less social cost by an alternative strategy. Margaret Wilson's analysis of the Employment Contracts Act is primarily concerned with the effect the Act has on the possibility of employment equality for women. This paper reviews both the past and current impact of legislation in terms of women's lack of bargaining strength and concludes that "the current provisions of the ECA make it unlikely that the substantive employment position will ever be improved." 
The Employment Contracts Act 1991 engendered considerable interest across the Tasmar and some state legislation has been enacted with marked similarities to the New Zealand legislation. Richard Mitchell and Richard Naughton examine the Employment Relations Act 1992 enacted in the State of Victoria. This legislation was also inspired by "New Right" philosophies and readers may experience a sense of deja $\mathrm{vu}$ reading about legislation based on ideas which "advocate the regulation of labour markets by voluntary agreement by employers and employees to the total, or at least substantial exclusion of unions and state intervention." This analysis concludes that many of the reforms have, as yet at least failed to reach their objectives.

Shortly after the Victorian changes, Western Australia followed suit with three new pieces of legislation in 1993. Ray Fells and Charles Mulvey discuss the new legislation, the central thrust of which was to permit "mutually consenting employees and their employers to opt out of the award system and to enter into either collective or individual workplace agreements instead." Since the changes in Western Australia are very recent, the authors are reluctant to pass judgments, but they do see these State legislative changes resulting in increased tensions between the State and Federal jurisdictions. Further changes ar anticipated.

Australian legislative changes have occurred only in the past year or two, but in Britain the process began with the election of Mrs Thatcher's Conservative Party in 1979. Since then, as John Goodman and Jill Earnshaw report, there have been regular changes to the legislation "aimed principally at regulating and curtailing many of the historical freedoms of trade unions, particularly in relation to industrial disputes, the closed shop and internal governance." This thrust by the British Conservatives has been matched by the drive by European Community lawmakers towards increased protective regulation, and Goodman and Earnshaw discuss the increasing tension between the two policy directions.

All five papers in the Symposium provide thoughtful analysis, interesting data and valuable insights into the changing role of the State in industrial relations. 